\title{
The Strategy Analysis of the Integration of Modern Information Technology and Class Teaching
}

\author{
Yuheng Zhao \\ Department of Foreign Languages, Ankang University, Ankang, Shanxi, 725000, China \\ Email: 15297059@qq.com
}

\begin{abstract}
The integration of modern information technology and class teaching is the aim of the teaching reform of modern education. In this paper, the writer discusses the basic strategies of this integration from the perspective of the application of educational technology and the education culture development.

Index Terms - information technology, the culture of education, curriculum integration

\section{Introduction}

The integration of information technology and class teaching is the necessity of the development of education informatization. The key venue of teaching is classrooms, if the integration needs to be achieved, educators should bring the information technology into class teaching. Thus, realizing the harmonious development of educational technology and education culture is the important safeguard of improving the quality of education and promoting the quality education.
\end{abstract}

\section{The Development of Information Technology}

The development of information technology promotes the modernization of educational technology. As the basis of education informatization, it can ensure the further development of the teaching reform. The integration is a process of combining the technology and education, so as to promote the study. The technology can provide students a bran-new way of learning. But the integration can be effective, only when students can use the technology to get, analyze and integrate the information, and finally put it into application. The information technology is somewhat systematic; it includes not only the modern teaching media, such as movie, $\mathrm{TV}$, and computer, but all the human resources and technical resources in the education as well. In the process of this integration, informationlizing the education, improving the teachers' technology practice ability and the students' information technology application ability should be involved.

\subsection{Education informatization}

\subsubsection{The informatization construction in school}

School network is an important infrastructure the in informatization construction. It includes the hardware construction, software construction and information resource construction. In terms of network architecture, modern school network mainly uses high-speed local area network to access to the Internet. In terms of hardware, servers, personal computers, printers and such should be equipped ; and in terms of software, besides the network operating system, large database management systems, web publishing system, email management systems, and security system are required too. Furthermore, teaching conditions should be improved actively for the development of informatization construction. The teaching conditions refer to regular classrooms, multimedia classrooms, computer rooms, classrooms, voice laboratory, micro-electro-electronic reading room, as well as broadcasting systems, closed-circuit television systems, multimedia and network system. It is not only the teachers' teaching and research base, but good stage for students to learn and practice.

\subsubsection{The construction of teaching resource library}

Teaching resources refer to the related resources which can assist the class teaching, roughly divided into teaching materials, support system and environment, anything even cover all contribute to teaching activities. Teaching resource database is the core of the teaching resource library, it has three levels: the basic level includes the media resource library (text, graphics, images, audio, animation, and video) and the index database. The middle part involves integrable ware library, courseware library, database, case studies library and the corresponding index library. And the top level refers to the web course database and index database. The core of the construction of teaching resource library is the resource database.

\subsubsection{Teaching resource retrieval technique development}

Resource retrieval technology is a very important technology in computer application; it has been widely used in many fields. In terms searching for teaching resources, it is crucial to apply the concept and knowledge to the resource retrieval to meet the needs of class teaching. In particular, if we can combine fragmented knowledge accumulation, knowledge sharing, and knowledge integration technology, it is possible to form increasingly rich metadata information eventually, thus the whole teaching resource system can be increased in value, and supplies the basic service to the reform and development of diversified teaching under the environment of new technologies.

\subsection{The improvement of teachers' technical application ability}

As the direct participants in teaching, teachers' technical application ability directly affects the teaching results of the integration of modern information technology and class teaching. The teachers who use technical ways with ease can easily integrate the technology with teaching. With the support 
of technologies, the integration has the basis for further development. In order to improve teachers' technical application ability, it's necessary to give related trainings to them, such as the training of general office software, multimedia application, programming software, courseware and software related to Web design. Furthermore, teaching and scientific researches, and academic discussion about the ways of improving modern education technology should be developed, so as to help the class teaching.

\subsection{The improvement of students' technical application ability}

In the process of teaching informatization, teachers have responsibilities to improve students ' information technology literacy, and enhance students ' learning abilities in class teaching. As an integral part of the national system of education engineering course, the information technology course should concentrate on improving students' awareness of using technology as a learning tool. Teachers should not only teach the knowledge of hardware and software of computer system, but also emphasize the students' application ability of information technologies and related learning software. Meanwhile, teachers should help students learn some of the cutting-edge knowledge of hardware, software, and new methods of operation in order to meet the requirement of development of information technology, help them improve independent learning and exploration, and also help their ability of making better use of information.

\section{Culture Cultivation under the Background of Information Technology Education and Teaching}

\subsection{The development of educational democracy}

Under the guidance of the idea of Harmonious Culture, education has the connotation of democracy. General education refers to educated men have equal rights to education, rights of personality, have equal rights to enjoy the views, as well as rights to participate in the educational process, such as equal opportunities in education. The narrow sense of educational democracy refers to the internal democracy in education, such as Democratic decision-making, democratic teacher-student relationship in education, democratic curriculum and teaching, and democratic educational evaluation. The goal of teaching is to cultivate the students who have the ability to learn independently and independent personality. Meanwhile, the goal is also the true embodiment of democratic learning development. Teachers and students are equal individuals in the process of educational democracy; therefore, achieving the harmonious development of the relationship between teachers and students is helpful for promoting the education. In terms of cultural background, education in China focused on teaching for a long time, but in the teaching process, students' subjective initiative is always ignored. The relationship between teachers and students is not democratic. So it is crucial to build democratic relationship between teachers and students. Teachers' responsibility is not only teaching, but also encouraging students to think and explore. Besides, teachers will increasingly become consultants, participants in exchanging view, leaders who help the students find problems rather than giving the truth only. On the other hand, information and network technology provides an open basis for the development of education. Open teaching recourses, open teaching process and teaching methods let students get rid of the shackle of time and space, then have more chances to learn.

\subsection{The promotion of teachers' teaching style}

Teaching style reflects the teacher's personality. In class teaching, good teaching style can be formed from colorful teaching contents, skilled application of technology, fluent and humorous language, fine and accurate writing on the blackboard, active teaching mind, and pleasant teaching atmosphere and such. Good teaching style embodies the firstclass teaching level, it is the good class culture formed from creativity, and the result of the effect of teachers' comprehensive knowledge. But information technology is just the assist of modern education; teachers can not misuse it and ignore the teaching contents. Thus, the loyalty to the educational cause and the rigorous scholarship is the important guarantee of forming a good teaching style.

\subsection{The improvement of students' information literacy}

Information culture is the general name of people's stable views, attitudes, and behavioral habits on information which reflects in every area of society. The narrow sense of information refers to computer culture and internet culture. Rapid development of information technology promotes the modernization of education, the level of students' information literacy directly affect the result of the integration of modern information technology and class teaching, furthermore, the cultivation of students' information literacy becomes the important target of quality education in school. With the further development of education reform, students participate in the activities of the construction and development of curriculum, in that process, finding, analyzing and solving problems will become the important contents in students' learning. The application of information technology can achieve the reorganization and unification of students and social information. The function of the class activities of the integration of information technology and class teaching is to make better use of that technology. Accessing information should be an approach, not an aim. So the core of the cultivation of students' information literacy should includes teaching students accurately understand the definition of the information culture, using the information rationally, and creating new information based on the analysis of some related information. The integration can also create the proper environment for the information culture; guide the students to select information correctly, and finally form good information literacy.

\section{References}

[1] Qin Xuanyun, etc. To the understanding of the mathematical experiment course teaching and the teaching process implementation method. Journal of engineering mathematics, 2002, 18 (6): 44-45. 
[2] B.J. Boutt'e (2001). "Information Technology Demystified," A Report from the UniForum Technical Steering Committee.

[3] Baljit Vohra (2007). "Banking in Iraq: The 21st century challenge" paper presented at Iraq Banking and Finance Conference, Amman, Jordan, 4 April.

[4] Berger A. N. (2003). "The economic effects of technological progress, Evidence from the banking industry," Journal of Money, Credit, and Banking, vol. 35, no. 2.
[5] Bernardo Bátiz-Lazo and Douglas Wood (2001), "Information technology Innovations and Commercial Banking": A Review and Appraisal from a Historical Perspective.

[6] Britni Must and Kathleen Ludewig (2010). Mobilemoney: Cell Phone Banking In Developing Countries. 